\title{
Correction to: Rhizosphere microbiomes diverge among Populus trichocarpa plant- host genotypes and chemotypes, but it depends on soil origin
}

Allison M. Veach ${ }^{1}$, Reese Morris ${ }^{1}$, Daniel Z. Yip ${ }^{1}$, Zamin K. Yang ${ }^{1}$, Nancy L. Engle ${ }^{1}$, Melissa A. Cregger ${ }^{1}$, Timothy J. Tschaplinski ${ }^{1}$ and Christopher W. Schadt ${ }^{1,2^{*}}$

Correction to: Microbiome 7, 76 (2019)

https://doi.org/10.1186/s40168-019-0668-8

Following publication of the original article [1], the authors identified an error in Fig. 2. The correct figure is given below.

Published online: 22 January 2021

\section{Reference}

1. Veach AM, Morris R, Yip DZ, et al. Rhizosphere microbiomes diverge among Populus trichocarpa plant-host genotypes and chemotypes, but it depends on soil origin. Microbiome. 2019;7:76 https://doi.org/10.1186/s40168-0190668-8.

* Correspondence: schadtcw@ornl.gov

'Biosciences Division, Oak Ridge National Laboratory, 1 Bethel Valley Rd, Oak Ridge, TN 37831-6038, USA

2Department of Microbiology, University of Tennessee, Knoxville, TN 37996, USA

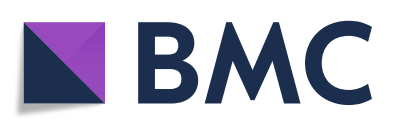

(- The Author(s). 2021 Open Access This article is licensed under a Creative Commons Attribution 4.0 International License, which permits use, sharing, adaptation, distribution and reproduction in any medium or format, as long as you give appropriate credit to the original author(s) and the source, provide a link to the Creative Commons licence, and indicate if changes were made. The images or other third party material in this article are included in the article's Creative Commons licence, unless indicated otherwise in a credit line to the material. If material is not included in the article's Creative Commons licence and your intended use is not permitted by statutory regulation or exceeds the permitted use, you will need to obtain permission directly from the copyright holder. To view a copy of this licence, visit http://creativecommons.org/licenses/by/ $4.0 /$ The Creative Commons Public Domain Dedication waiver (http://creativecommons.org/publicdomain/zero/1.0/) applies to the data made available in this article, unless otherwise stated in a credit line to the data. 


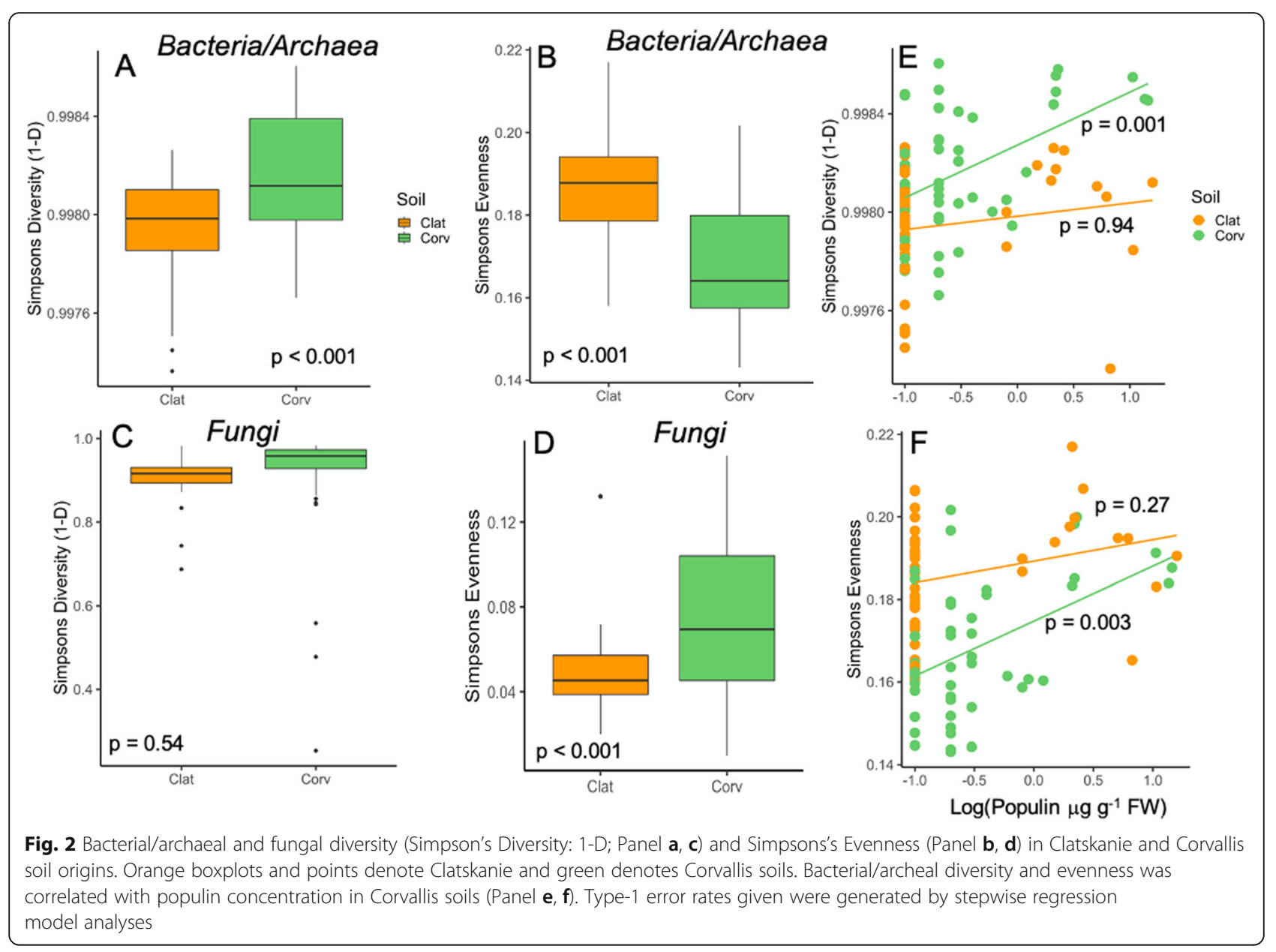

